
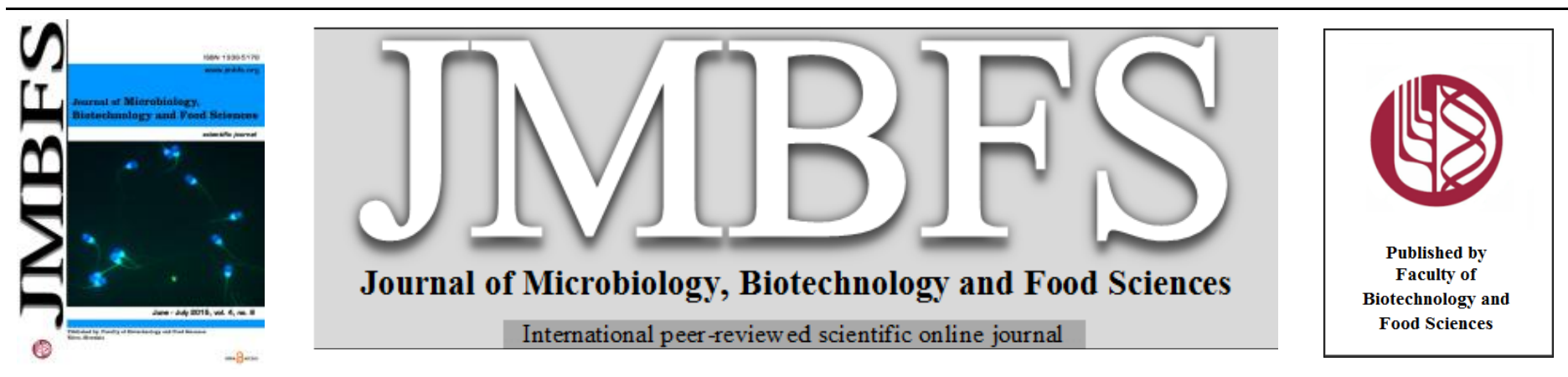

\title{
COMPOSITIONAL PROPERTIES OF THREE FRESHWATER CARP SPECIES GROWN IN BRACKISH WATER
}

\section{Muhammad Ismail Chughtai*, Uzma Maqbool and Rashid Ahmed}

\begin{abstract}
Address(es): Animal Sciences Division, Nuclear Institute for Agriculture \& Biology (NIAB), P.O. Box 128, Faisalabad 38000, Pakistan.
\end{abstract}
*Corresponding author: nishat_dgk@yahoo.com

doi: 10.15414/jmbfs.2015.4.6.532-535

ARTICLE INFO

Received 20.1.2015

Revised 3. 3. 2015

Accepted 10. 3. 2015

Published 1. 6. 2015

Regular article open $\mathcal{O}$ access

\begin{abstract}
Three freshwater fish species viz. Labeo rohita, Cirrhinus mrigala and Gibelion catla, grown in brackish water ponds were analyzed for compositional properties to assess the potential of this habitat to produce nutritionally adequate fish for human consumption. Overall, the unsaturated fatty acids were lower in L. rohita (46.6\%) than saturated fatty acids; while in C. mrigala and G. catla, the unsaturated fatty acids were $50.4 \%$ and $58.2 \%$, respectively. The most abundant saturated fatty acid in examined species was palmitic acid $\left(\mathrm{C}_{16: 0}\right)$, 23.7 to $34.1 \%$; mono-unsaturated fatty acid was oleic acid $\left(\mathrm{C}_{18: 1}\right) 19.6$ to $31.7 \%$ and poly-unsaturated fatty acid linoleic acid $\left(\mathrm{C}_{18: 2}\right) 9.46$ to $13.3 \%$. A reasonable amount of essential fatty acids $\omega-3$ (5.80 to $9.26 \%)$ and $\omega-6$ (9.46 to $13.3 \%)$ was also found in these species while growing in brackish water on salt tolerant forages like Leptochloa fusca, Brachiaria mutica and Kochia indica as supplemental feed. The $\omega-3 / \omega-6$ ratio was calculated as $0.46,0.80$ and 0.69 in L. rohita, C. mrigala and G. catla, respectively. The maximum EPA (eicosapentaenoic acid, $\mathrm{C}_{20: 5}$ ) was observed in C. mrigala $(2.23 \%)$, followed by G. catla $(1.62 \%)$ and L. rohita $(0.98 \%)$. While the DHA (docosahexanenoic acids, $\mathrm{C}_{22: 6}$ ) was found maximum in $G$. catla $(1.97 \%)$ and minimum in C. mrigala $(0.95 \%)$. The results of body composition indicated that $L$. rohita found maximum protein contents (19.2\%) with minimum total fats (1.28\%) while $C$. mrigala found maximum total fats $(2.11 \%)$ but minimum protein contents $(18.3 \%)$. Overall results indicated that the Indian carps grown in brackish water have comparable chemical composition and nutritive value with the same species grown in freshwater medium.
\end{abstract}

Keywords: Indian carps, brackish water, chemical composition, fatty acids profile

\section{INTRODUCTION}

In Asian countries, the Indian carps are commonly cultured in freshwater ponds under semi-conservative system. These carp species contribute a major proportion of fish production with over 1.8 million tonnes (FAO, 2003). Fish is considered as the fastest growing food source in Asia as it provides $26.2 \%$ of total meat (Delgado et al., 2002). The most preferred Indian carp is Labeo rohita which is extensively cultured in the Indian sub-continent (Misra and Samantaray, 2004). Fish is widely consumed in Pakistan but still very low per capita consumption $(1.7 \mathrm{~kg})$. Only $26 \%$ of total fish production is consumed domestically, $19 \%$ being exported and 55\% used for fish meal (Wasim, 2007).

Fish is a good source of dietary protein and high in unsaturated fatty acids, essential amino acids, vitamins and minerals. Fish lipids have protective role against cardiovascular diseases, stroke, hypertension, diabetes, depression and rheumatoid arthritis (Karanth et al., 2009; Hussain et al., 2011). Coronary heart disease has been identified as a main cause of death in various parts of the world including Pakistan and those peoples who consume more fish have less chances of this disease (Hassan et al., 2010; Afkhami et al., 2011). The quantity of total lipids varies among different fish species. The type of fatty acids present as free acid or as neutral lipid also differs from species to species and or its aqueous medium (Saify et al., 2000). Fish quality is important for rural communities because it contributes to their healthy diets and livelihoods (Jabeen and Chaudhry, 2011).

The nutritional parameters are attributed to the diet which they consume and their ecological conditions. Marine fish and its products are high in health promoting fatty acids but required in very small amount in human diet (Sargent, 1997). The fatty acid composition in fish oil is affected by several factors including geographical location, temperature and water salinity. The concentration of eicosapentaenoic acid in fish oil increased due to increase in temperature and decrease in water salinity (Razak et al., 2001). Fish is also a good source of antimicrobial peptides used for defense against pathogens (Ravichandran $\boldsymbol{e t}$ al., 2010). The most important feature in the fatty acid profile of fish is the high content of essential poly-unsaturated fatty acids such as eicosapentaenoic acid and docosahexaenoic acid (Wu and Peter, 2008; Ravichandran et al., 2011).

The supplemental feed plays a significant role in growth and chemical composition of fish (Jankowska et al., 2007). The body composition is a good indicator to assess the nutritional status and condition of fish which are essential parameters to check the quality characteristics of farmed fish for human consumption (Ali et al., 2005). An attempt has been made to study the nutritional value and fatty acids composition of brackish water fish fed on salt-tolerant forages under semi-intensive polyculture system. The present study will provide baseline data on some of the important chemical constituents as there is limited data on chemical properties of brackish water fish.

\section{MATERIALS AND METHODS}

\section{Study site}

The study was conducted at Bio-Saline Research Station, Pakka Anna (lat $31^{\circ} .24^{\prime} \mathrm{N}$ and long. $73^{\circ} .05^{\prime} \mathrm{E}$ ) of the Nuclear Institute for Agriculture and Biology (NIAB), Faisalabad, Pakistan, which is located at a distance of $50 \mathrm{~km}$ in South-West of the Faisalabad city, with an elevation of $190 \mathrm{~m}$ above sea level. The climate is semi-arid with an annual average rainfall of $325 \mathrm{~mm}$ and evaporation exceeds $1600 \mathrm{~mm}$. The annual average temperature in the area is $32^{\circ} \mathrm{C}$.

\section{Fish sampling}

Three fish species viz. Labeo rohita, Cirrhinus mrigala and Gibelion catla, grown in brackish water ponds (dimensions $25 \mathrm{~m} \times 13 \mathrm{~m} \times 1.5 \mathrm{~m}$ ) under semiintensive polyculture system, were selected to study their chemical composition Fish samples with average weight $217 \pm 9.89 \mathrm{~g}$ and length $27.3 \pm 0.30 \mathrm{~cm}$, were collected (twelve specimens of each species) in 2013. These fishes were fed on salt-tolerant forages including Leptochloa fusca (Kallar grass), Brachiaria mutica (Para grass) and Kochia indica (Kochia) as supplemental feed on daily basis. The ponds were also fertilized with goat droppings and nitrophos @ 6000 and $7.5 \mathrm{~kg}$ $\mathrm{ha}^{-1}$, respectively.

\section{Morphometric measurements}

The fish samples were immediately transported to the laboratory where morphometric measurements including wet weight, head length, snout length, eye 
diameter, length of pectoral, dorsal, ventral, anal and caudal fins, standard length, forked length, total length, number of fin rays and scales area of each sample were carried out. After morphometric measurements, each fish sample was dissected, its internal organs removed and then washed to remove residual blood After removing skin, the fish fillets were obtained by cutting the fish lengthwise along the backbone to obtain maximum flesh without including the backbone. The fillets were cut in to small pieces and transferred into labeled sterilized polythene bags and stored in freezer at $-20^{\circ} \mathrm{C}$ until further analysis.

\section{Proximate composition}

Whole body composition analysis was carried out by using standard methods (AOAC, 2003). Water content was determined by placing whole fish in preweighed aluminum foil tray for drying in an electric oven at $105^{\circ} \mathrm{C}$ till constant weight. Total ash contents were calculated gravimetrically following ignition of samples in muffle furnace at $550^{\circ} \mathrm{C}$ until constant weight. Crude protein $(\mathrm{N} \times 6.25)$ was determined using the Kjeldahl method. Lipids were extracted by adopting the procedure as described by Bligh and Dyer (1959) with some modification by Kinsella et al. (1977). The total carbohydrates were calculated by the difference method. Sodium and potassium were measured with flame photometer (Model PFP-7, Jenway) while phosphorus was spectrophotometer (Model U-2800, Hitachi).

\section{Preparation of methyl esters}

Fish oil samples were converted to their constituent fatty acid methyl esters by using an improved, rapid base-catalyzed transesterification method described by Ichibara et al. (1996). Up to $10 \mathrm{mg}$ of fish oil was dissolved in $2 \mathrm{ml}$ hexane followed by the addition of $0.2 \mathrm{M}$ methanolic potassium hydroxide. The tube was vortexed for 2 minutes at room temperature. After a light centrifugation, an aliquot of the hexane layer was separated and transferred in capped test tubes for gas chromatographic analysis. Same procedure was adopted for the preparation of all samples.

\section{Gas chromatography}

A GC system (Agilent, 7890A, USA), equipped with FID and DB-23 capillary column (length $30 \mathrm{~m}$, I.D $0.25 \mathrm{~mm}$, film thickness $0.25 \mu \mathrm{m}$ ) was used for the analysis of methyl esters of fish oils. The injector and detector temperatures were set at 250 and $300^{\circ} \mathrm{C}$, respectively. The column oven temperature was programmed from 180 to $210^{\circ} \mathrm{C}$ at the rate $20^{\circ} \mathrm{C}$ per minute; initial and final temperatures were held for 5 and 14 minutes, respectively. Nitrogen was used as carrier gas with a flow of $2 \mathrm{ml}$ per minute. Hydrogen and synthetic air were used as supportive gases. A sample of $1.0 \mu \mathrm{L}$ was injected by using split mode (split ratio 1:75). Fatty acid methyl esters were analyzed by using external standards Retention times and peak area percentages were automatically computed by Agilent ChemStation program. The composition was reported as a relative percentage of the total peak area.

\section{Statistical analysis}

All the data is expressed as means \pm standard deviation. The values of proximate composition and fatty acid profile of each species were compared by one-way analysis of variance followed by Duncan's multiple range tests. All analyses were conducted by using MSTAT-C program (Freed and Scott, 1989).

\section{RESULTS AND DISCUSSION}

Table 1 shows the morphometric measurements of fish samples collected from brackish water ponds at Bio-saline research Station, Pakka Anna (Faisalabad). The brackish groundwater was used throughout the growing period. Results of water analysis indicated that the water temperature varied from 16.2 to $33.1^{\circ} \mathrm{C}$. The $\mathrm{pH}$ and water salinity (electrical conductivity-EC) ranged from 8.23 to 8.80 and 5.17 to 6.37 desi Siemens per meter $\left(\mathrm{dS} \mathrm{m} \mathrm{m}^{-1}\right)$, respectively. The $\mathrm{pH}$ of water remained within limit of 7.5 to 9.0 (Pailwan et al., 2008). Yadav (2006) investigated the lethal alkaline limit for fish which is $\mathrm{pH} 11$. The average dissolved $\mathrm{O}_{2}$ was observed $5.81 \mathrm{mg} \mathrm{L}^{-1}$. Banarjee and Lal (1990) reported 5 to $10 \mathrm{mg} \mathrm{L}^{-1}$ dissolved $\mathrm{O}_{2}$ as an ideal range for fish production. The free $\mathrm{CO}_{2}$ was fluctuated between 8.57 to $11.6 \mathrm{mg} \mathrm{L}^{-1}$. Similarly, the pond's soil up to $150 \mathrm{~cm}$ depth was also analyzed. The maximum value of EC $\left(19.6 \mathrm{dS} \mathrm{m}^{-1}\right)$ was observed in soil profile at $120-150 \mathrm{~cm}$ depth. The overall soil texture of all fish ponds indicated the textural class as sandy loam.

Table 1 Morphometric measurements of three carp species, grown in brackish water

\begin{tabular}{|c|c|c|c|}
\hline Variables & Labeo rohita & Cirrhinus mrigala & Gibelion catla \\
\hline Wet weight (g) & $235.4 \pm 9.89$ & $210.3 \pm 11.5$ & $206.7 \pm 8.62$ \\
\hline Head length $(\mathrm{cm})$ & $5.80 \pm 0.14$ & $5.23 \pm 0.20$ & $6.23 \pm 0.25$ \\
\hline Snout length $(\mathrm{cm})$ & $1.85 \pm 0.07$ & $1.47 \pm 0.11$ & $2.23 \pm 0.24$ \\
\hline Eye diameter (mm) & $9.50 \pm 0.15$ & $10.1 \pm 0.10$ & $8.80 \pm 0.12$ \\
\hline Standard length $(\mathrm{cm})$ & $21.9 \pm 0.14$ & $22.7 \pm 0.25$ & $19.5 \pm 0.30$ \\
\hline Forked length $(\mathrm{cm})$ & $23.1 \pm 0.15$ & $25.5 \pm 0.17$ & $21.7 \pm 0.23$ \\
\hline Total length $(\mathrm{cm})$ & $26.6 \pm 0.10$ & $29.8 \pm 0.30$ & $25.5 \pm 0.50$ \\
\hline Length of pectoral fin $(\mathrm{cm})$ & $4.15 \pm 0.12$ & $4.63 \pm 0.19$ & $3.77 \pm 0.21$ \\
\hline Length of dorsal fin $(\mathrm{cm})$ & $4.55 \pm 0.07$ & $5.03 \pm 0.08$ & $4.63 \pm 0.11$ \\
\hline Length of ventral fin $(\mathrm{cm})$ & $4.10 \pm 0.14$ & $3.86 \pm 0.11$ & $4.07 \pm 0.05$ \\
\hline Length of anal fin $(\mathrm{cm})$ & $4.45 \pm 0.11$ & $4.20 \pm 0.21$ & $4.12 \pm 0.10$ \\
\hline Length of caudal fin $(\mathrm{cm})$ & $5.65 \pm 0.05$ & $6.30 \pm 0.08$ & $6.10 \pm 0.10$ \\
\hline No. of pectoral fin rays & $11.3 \pm 0.57$ & $14.0 \pm 0.34$ & $12.3 \pm 0.58$ \\
\hline No. of dorsal fin rays & $12.4 \pm 0.57$ & $13.3 \pm 0.57$ & $10.7 \pm 0.58$ \\
\hline No. of ventral fin rays & $14.3 \pm 0.57$ & $8.33 \pm 0.57$ & $6.67 \pm 0.58$ \\
\hline No. of anal fin rays & $7.33 \pm 0.57$ & $7.67 \pm 0.57$ & $7.33 \pm 1.53$ \\
\hline No. of caudal fin rays & $25.6 \pm 1.53$ & $21.3 \pm 1.53$ & $20.3 \pm 0.58$ \\
\hline Area of scales $\left(\mathrm{cm}^{2}\right)$ & $0.36 \pm 0.02$ & $0.52 \pm 0.01$ & $0.51 \pm 0.02$ \\
\hline
\end{tabular}

Values are mean of six samples \pm Standard deviation

Results of the chemical composition of three carp species are presented in Table 2. C. mrigala and G. catla showed comparable moisture contents but differed significantly $(p \leq 0.05)$ from $L$. rohita. The moisture contents in the examined fish species were in the range observed by other authors (Abii $\boldsymbol{e t}$ al., 2007). The $L$. rohita was highest in moisture and crude protein content but lowest in total fats whereas $C$. mrigala was lowest in moisture and crude protein content but highest in total fats. Fish proteins contain all essential amino acids for the human beings (Vladau et al., 2008). In mammals and fish, the protein usually ranges from 14 to 20\% (Cirkovic et al., 2010). The lipid contents vary depending on fish type, time of year and feed used for fish (Guler et al., 2008). Rahman et al. (1995) classified fish on the basis of fat contents as lean fish (fat $<5 \%$ ), medium fat fish (fat $5-10 \%$ ) and fatty fish (fat $>10 \%$ ). Based on this classification, the examined fish species are classified as lean fish. Results were contrary to Jabeen and Chaudhry (2011) who studied these fish species grown in freshwater medium.
This difference may be due to sampling season, supplemental feed type and growth medium. The difference is clear that in the present study the supplemental feed source was salt-tolerant forages and the growing medium was brackish pond water. May be due to this reason the examined species were lean with $<5 \%$ fat while the same species grown in freshwater were medium fat with $5-10 \%$ fat Similarly, the protein contents in L. rohita and G. catla were slightly higher than the level reported by FAO (2008).

The mean ash contents in $L$. rohita and $G$. catla were similar but differed significantly $(p \leq 0.05)$ with $C$. mrigala. The phosphorus concentration was observed maximum $\left(60.8 \mathrm{mg} \mathrm{g}^{-1}\right)$ in $G$. catla and minimum $\left(43.3 \mathrm{mg} \mathrm{g}^{-1}\right)$ in $C$. mrigala. Similarly, the sodium was found maximum $\left(11.6 \mathrm{mg} \mathrm{g}^{-1}\right)$ in G. catla while minimum $\left(10.8 \mathrm{mg} \mathrm{g}^{-1}\right)$ in L. rohita. There was no significant difference in potassium concentration among the examined fish species (Table 2). 
Table 2 Chemical composition of three carp species, grown in brackish water

\begin{tabular}{|c|c|c|c|}
\hline Body constituents & Labeo rohita & Cirrhinus mrigala & Gibelion catla \\
\hline Moisture (\%) & $75.1 \pm 2.45^{\mathrm{a}}$ & $72.7 \pm 3.14^{\mathrm{b}}$ & $73.8 \pm 2.71^{\mathrm{ab}}$ \\
\hline Dry matter $(\%)$ & $24.6 \pm 1.52^{\mathrm{ab}}$ & $28.3 \pm 1.96^{\mathrm{a}}$ & $28.2 \pm 1.03^{\mathrm{a}}$ \\
\hline Crude protein $(\%)$ & $19.2 \pm 3.21^{\mathrm{a}}$ & $18.3 \pm 2.01^{\mathrm{b}}$ & $19.1 \pm 2.50^{\mathrm{a}}$ \\
\hline Total fats $(\%)$ & $1.28 \pm 0.21^{\mathrm{b}}$ & $2.11 \pm 0.56^{\mathrm{a}}$ & $1.84 \pm 0.10^{\mathrm{ab}}$ \\
\hline Total ash (\%) & $3.32 \pm 0.19^{\mathrm{b}}$ & $5.56 \pm 0.35^{\mathrm{a}}$ & $3.45 \pm 0.11^{\mathrm{b}}$ \\
\hline Carbohydrates (\%) & $1.10 \pm 0.08^{\mathrm{b}}$ & $1.33 \pm 0.11^{\mathrm{b}}$ & $1.81 \pm 0.15^{\mathrm{a}}$ \\
\hline Phosphorus ( $\mathrm{mg} \mathrm{g}^{-1}$ ) & $58.7 \pm 3.34^{b}$ & $43.3 \pm 3.71^{\mathrm{b}}$ & $60.8 \pm 4.21^{\mathrm{a}}$ \\
\hline Sodium $\left(\mathrm{mg} \mathrm{g}^{-1}\right)$ & $10.8 \pm 2.15^{\mathrm{ab}}$ & $11.1 \pm 1.09^{\mathrm{a}}$ & $11.6 \pm 1.14^{\mathrm{a}}$ \\
\hline Potassium $\left(\mathrm{mg} \mathrm{g}^{-1}\right)$ & $7.30 \pm 1.02^{\mathrm{a}}$ & $7.70 \pm 0.89^{\mathrm{a}}$ & $7.30 \pm 0.62^{\mathrm{a}}$ \\
\hline
\end{tabular}

Table 3 Fatty acid profile (\%) of three carp species, grown in brackish water

\begin{tabular}{|c|c|c|c|c|}
\hline Fatty acids & Retention time (min.) & Labeo rohita & Cirrhinus mrigala & Gibelion catla \\
\hline \multicolumn{5}{|l|}{ Saturated fatty acids } \\
\hline Caproic acid, $\mathrm{C}_{6: 0}$ & 2.315 & $0.03 \pm 0.01^{\mathrm{b}}$ & $0.25 \pm 0.01^{\mathrm{ab}}$ & $0.54 \pm 0.02^{\mathrm{a}}$ \\
\hline Caprylic acid, $\mathrm{C}_{8: 0}$ & 2.517 & $0.32 \pm 0.02^{\mathrm{a}}$ & $0.09 \pm 0.01^{\mathrm{b}}$ & $0.25 \pm 0.01^{\mathrm{ab}}$ \\
\hline Capric acid, ' $\mathrm{C}_{10: 0}$ & 2.773 & 0.00 & $0.02 \pm 0.00^{\mathrm{a}}$ & $0.04 \pm 0.01^{\mathrm{a}}$ \\
\hline Lauric acid, $\mathrm{C}_{12: 0}$ & 3.256 & $0.01 \pm 0.00^{\mathrm{b}}$ & $0.23 \pm 0.02^{\mathrm{a}}$ & $0.62 \pm 0.01^{\mathrm{a}}$ \\
\hline Tridecanoic acid, $\mathrm{C}_{13: 0}$ & 3.604 & $0.56 \pm 0.02^{\mathrm{a}}$ & $0.08 \pm 0.01^{\mathrm{c}}$ & $0.29 \pm 0.01^{\mathrm{b}}$ \\
\hline Myristic acid, $\mathrm{C}_{14: 0}$ & 4.023 & $3.25 \pm 0.14^{\mathrm{a}}$ & $2.32 \pm 0.01^{b}$ & $2.92 \pm 0.05^{\mathrm{ab}}$ \\
\hline Pentadecanoic acid, $\mathrm{C}_{15: 0}$ & 4.493 & $1.68 \pm 0.02^{\mathrm{a}}$ & $0.85 \pm 0.02^{\mathrm{b}}$ & $0.73 \pm 0.01^{b}$ \\
\hline Palmitic acid, $\mathrm{C}_{16: 0}$ & 5.036 & $31.97 \pm 1.10^{\mathrm{a}}$ & $34.12 \pm 1.12^{\mathrm{a}}$ & $23.66 \pm 2.12^{\mathrm{b}}$ \\
\hline Heptadecanoic acid, $\mathrm{C}_{17: 0}$ & 5.652 & $3.02 \pm 0.03^{\mathrm{a}}$ & $1.58 \pm 0.02^{\mathrm{b}}$ & $2.60 \pm 0.01^{\mathrm{ab}}$ \\
\hline Stearic acid, $\mathrm{C}_{18: 0}$ & 6.385 & $11.25 \pm 0.15^{\mathrm{a}}$ & $8.94 \pm 0.21^{\mathrm{bc}}$ & $9.80 \pm 0.11^{\mathrm{b}}$ \\
\hline Arachidic acid, $\mathrm{C}_{20: 0}$ & 8.279 & $0.43 \pm 0.01^{\mathrm{a}}$ & $0.71 \pm 0.01^{\mathrm{a}}$ & $0.24 \pm .0 .02^{\mathrm{b}}$ \\
\hline Behenic acid, $\mathrm{C}_{22: 0}$ & 8.641 & $0.84 \pm 0.01^{\mathrm{a}}$ & $0.45 \pm 0.01^{\mathrm{ab}}$ & $0.12 \pm .0 .01^{\mathrm{b}}$ \\
\hline Total SFAs & - & 53.37 & 49.64 & 41.83 \\
\hline \multicolumn{5}{|l|}{ Mono-unsaturated fatty acids } \\
\hline Myristoleic acid, $C_{14: 1} n-5$ & 4.242 & $0.67 \pm 0.01^{\mathrm{ab}}$ & $1.22 \pm 0.01^{\mathrm{a}}$ & $1.08 \pm 0.02^{\mathrm{a}}$ \\
\hline Palmitoleic acid, $C_{16: 1} n-7$ & 5.250 & $7.02 \pm 0.04^{\mathrm{a}}$ & $5.12 \pm 0.03^{b}$ & $2.23 \pm 0.01^{\mathrm{c}}$ \\
\hline Oleic acid, $C_{18: 1} n-9$ & 6.643 & $19.61 \pm 1.01^{\mathrm{c}}$ & $26.23 \pm 1.25^{\mathrm{b}}$ & $31.71 \pm 1.17^{\mathrm{a}}$ \\
\hline Erucic acid, $C_{22: 1} n-9$ & 11.716 & $0.96 \pm 0.04^{\mathrm{a}}$ & $0.74 \pm 0.02^{\mathrm{a}}$ & $0.57 \pm 0.01^{\mathrm{a}}$ \\
\hline Total MUFAs & - & 28.27 & 33.31 & 35.59 \\
\hline \multicolumn{5}{|l|}{ Poly-unsaturated fatty acids } \\
\hline Linoleic acid, $C_{18: 2} n-6$ & 7.097 & $12.57 \pm 0.18^{\mathrm{a}}$ & $9.46 \pm 0.25^{\mathrm{b}}$ & $13.32 \pm 0.14^{\mathrm{a}}$ \\
\hline Linolenic acid, $C_{18: 3} n-3$ & 7.721 & $3.15 \pm 0.2^{\mathrm{ab}}$ & $4.41 \pm 0.02^{\mathrm{ab}}$ & $5.67 \pm 0.05^{\mathrm{a}}$ \\
\hline Eicosapentaenoic acid, $C_{20: 5} n-3$ & 8.641 & $0.98 \pm 0.02^{b}$ & $2.23 \pm 0.01^{\mathrm{a}}$ & $1.62 \pm 0.01^{b}$ \\
\hline Docosahexaenoic acid, $\mathrm{C}_{22: 6} \mathrm{n}-3$ & 11.945 & $1.67 \pm 0.01^{\mathrm{a}}$ & $0.95 \pm 0.01^{\mathrm{a}}$ & $1.97 \pm 0.01^{\mathrm{a}}$ \\
\hline Total PUFAs & - & 18.36 & 17.05 & 22.58 \\
\hline$\omega-3 / \omega-6$ ratio & - & 0.46 & 0.80 & 0.69 \\
\hline$\omega-6 / \omega-3$ ratio & - & 2.16 & 1.25 & 1.44 \\
\hline SFT:USFA ratio & - & 1.14:1 & 1:1.01 & 1:1.39 \\
\hline
\end{tabular}

Values are mean of six samples \pm Standard deviation; Means within a row with different superscript letter are significantly different $(p \leq 0.05)$

The results of fatty acid profiles of all examined carp species are presented in Table 3. Total saturated fatty acids (SFAs) in lipids were 53.4, 49.6 and $41.8 \%$ in L. rohita, C. mrigala and G. catla, respectively. Among SFAs, myristic, palmitic, heptadecanoic and stearic acids were dominating fatty acids. Palmitic acid was the primary SFA, contributing about 56 to $68 \%$ to the total SFA contents of lipids in all species. Total mono-unsaturated fatty acids (MUFAs) in L. rohita, C. mrigala and $G$. catla were calculated as $28.3,33.3$ and $35.6 \%$, respectively, where the palmitoleic and oleic acids were the dominating MUFAs. Oleic acid contributed about $69-85 \%$ to the total MUFAs similar to the results of Osman $\boldsymbol{e}$ al. (2007). Among SFAs and MUFAs, the highest palmitic acid followed by oleic acid and stearic acid was comparable with the findings of Luczynska $\boldsymbol{e t}$ al. (2008) and Jabeen and Chaudhry (2011).

Total poly-unsaturated fatty acids (PUFAs) were $18.4,17.1$ and $22.6 \%$ in $L$. rohita, C. mrigala and G. catla, respectively with highest concentrations of linoleic and linolenic acids. This may be due to phytoplankton feeding habit as they are good source of these essential fatty acids. The maximum amount of EPA $(2.23 \%)$ was observed in C. mrigala and minimum $(0.98 \%)$ in L. rohita Similarly, the maximum percentage of DHA was observed in G. catla (1.97), followed by L. rohita (1.67) and C. mrigala (0.95).
The values of EPA and DHA were lower in L. rohita as compared to other experimental fish species which is may be due to low fat contents. Simopoulos (2002) recommended the $\omega-3: \omega-6$ appropriate balance from 1.1 to 1.4 depending on the disease. The ratio of $\omega-3$ and $\omega-6$ fatty acids has been suggested a useful indicator to compare the nutritional values of fish oils which depends on species, period of year, age, size, reproduction period and the fatty acids in diet (Sirot $\boldsymbol{e t}$ al., 2008). In the present study, the amount of $\omega-3$ fatty acids and $\omega-3: \omega-6$ ratio was lower than the findings of Ugoala et al. (2009). The levels of $\omega-6$ fatty acids were higher than $\omega-3$ fatty acids in examined fish species similar to the findings of Aras et al. (2003). The recommended daily intake of $\omega-3$ fatty acids is ranged from 0.5 to $1.6 \mathrm{~g}$ for healthy adults, infants, pregnant and lactating women (Cejas, 2000).

\section{CONCLUSION}

The Indian carps cultured in brackish water using salt-tolerant forages as supplemental feed are characterized by high protein content, reasonable amount of essential fatty acids ( $\omega-3$ and $\omega-6)$ and satisfactory proportion of n-3 and n-6 poly-unsaturated fatty acids especially linoleic acid. So, it is concluded that these carp species have comparable proximate compositions and fatty acid profiles 
with the same species grown in freshwater medium and is nutritionally aequate for human consumption.

Acknowledgments: The authors are thankful to the Mr. Abdul Rasul Awan, Officer Incharge (Bio-saline Research Station, Pakka Anna) for facilitation of saline aquaculture activities and field staff who aided in data collection, care of fish and fish sampling.

\section{REFERENCES}

ABII, T.A., AFIEROHO, O.E., NNAMDI, F.U. 2007. Comparative assessment of heavy metals in Oreochromis niloticus Tilapia (from the Michael Okpara University of Agriculture, Umudike) freshwater fish pond in Abia State with those from Uzere freshwater pond in Delta state of Nigeria. J. Fish. Int., 2(3), 226-230.

AFKHAMI, M., MOKHLESI, A., BASTAMI, K.D., KHOSHNOOD, R. ESHAGHI, N., EHSANPOUR, M. 2011. Survey of some chemical compositions and fatty acids in cultured Common carp (Cyprinus Carpio) and Grass carp (Ctenopharyngodon idella), Noshahr, Iran. World J. Fish \& Marine Sci., 3(6), 533-538.

ALI, M., IQBAL, F., SALAM, A., SIAL, F., ATHAR, M. 2005. Comparative study of body composition of four fish species in relation to pond depth. Int. J. Environ. Sci. \&Tech. 2(4), 359-364. http://dx.doi.org/10.1007/bf03325897

AOAC. 2003. Official methods of analysis. Association of Official Analytical Chemists (AOAC) International, Arlington, Virginia.

ARAS, N.M., HALILOGLU, H.I., YETIM, H., AYIK, O. 2003. Comparison of fatty acid profiles of different tissues of mature trout (Salmo trutta labrax, Pallas, 1811) caught from Kazandere Creek in the Oruh Region, Erzurum, Turkey. Turk J. Vet. Anim. Sci., 27, 311-316.

BANERJEE, R.K., LAL, B., 1990. Role of soil and water in fish farming with special reference to fish production. In: SAGUNAN, V.V., BHAUMIK, U. (Eds.). Technologies for inland fisheries development. pp: 123-129. Central Inland Capture Fisheries Research Institute Barrackpore, West Bengal.

BLIGH, E.G., DYER, W.J. 1959. A rapid method of total lipid extraction and purification. Can. J. Biochem. Physiol., 37, 911-917.

CEJAS, J.R. 2000. T-3 Fatty acids and health. British Nutrition Foundation, 8, 8. CIRKOVIC, M., TRBOVIC, D., MILOSEVIC, N., DORDEVIC, V. JANKOVIC, S., LJUBOJEVIC, D. 2010. Meat quality of two years-old tench and carp grown in extensive conditions. XIV International Symposium Feed Technology, 19-21 October, Novi Sad.

DELGADO, C., ROSEGRANT, M., WADA, N., MEIJER, S. AHMED, M. 2002. Fish as food: Projections to 2020 under different scenarios. International Food Policy Research Institute, 2033 K Street, N.W. Washington, DC. 2006, USA.

FAO. 2003. Aquaculture production. Volume 96. Food and Agriculture Organization of the United Nations, Rome, Italy.

FAO. 2008. Main elements of fish muscle. Fisheries and Aquaculture Department, Rome, Italy.

FREED, R.D., SCOTT, E. 1989. MSTAT-C Software. Michigan State University, USA.

GULER, G.O., KIZTANIR, B., AKTUMSEK, A., CITIL, O.B., OZPARLAK, H 2008. Determination of the seasonal changes on total fatty acid composition and $\omega-3 / \omega-6$ ratios of carp (Cyprinus Carpio L.) muscle lipids in Beysehir Lake (Turkey). Food Chem., $\quad 108, \quad 689-694$ http://dx.doi.org/10.1016/j.foodchem.2007.10.080

HASSAN, M., CHATHA, S.A.S., TAHIRA, I., HUSSAIN, B. 2010. Total lipids and fatty acid profile in the liver of wild and farmed Catla catla fish. Grasas $Y$ Aceites, 61(1), 52-57. http://dx.doi.org/10.3989/gya.032009

HUSSAIN, B., MAHBOOB, S., HASSAN, M., NADEEM, S., SULTANA, T. 2011. Effect of maturation degree on fatty acid profile of different tissues in wild and farmed Rohu (Labeo rohita). Grasas Y Aceites, 62(2), 206-212. http://dx.doi.org/10.3989/gya.090510

ICHIBARA, K., SHIBAHARA, A., YAMAMOTO, K., NA-KAYAMA, T. 1996 An improved method for rapid analysis of the fatty acids of glycerolipids. Lipids 31, 535-539. http://dx.doi.org/10.1007/bf02522648

JABEEN, F., CHAUDHRY, A.S. 2011. Chemical compositions and fatty acid profiles of three freshwater fish species. Food Chem.,125, 991-996. http://dx.doi.org/10.1016/j.foodchem.2010.09.103

JANKOWSKA, B., ZAKES, Z., ZMIJEWSKI, T, SZCZEPKOWSKI, M. KOWALSKA, A. 2007. Slaughter yield, proximate composition, and flesh colour of cultivated and wild perch (Perca fluviatilis L.). Czech. J. Anim. Sci., 52(8), 260-267.

KARANTH, S., SHARMA, P., PAL, K., VENKATESHWARLU, G. 2009. Effect of different vegetable oils on growth and fatty acid profile of Rohu (Labeo rohita, Hamilton); evaluation of a return fish oil diet to restore human cardioprotective fatty acids. Asian-Aust. J. Anim. Sci., 22(4), 565 - 575. http://dx.doi.org/10.5713/ajas.2009.80301

KINSELLA, J.E., SHIMP, J.L., MAI, J., WEIHRAUCH, J. 1977. Fatty acid content and composition of freshwater finfish. J. Am. Oil Chem. Soc., 54, 424429. http://dx.doi.org/10.1007/bf02671025
LUCZYNSKA, J., BOREJSZO, Z., LUCZYNSKI, M.J. 2008. The composition of fatty acids in muscles of six freshwater fish species from the Mazurian Great Lakes (North eastern Poland). Arch. Pol. Fish., 16(2), 167-178. http://dx.doi.org/10.2478/s10086-008-0014-4

MISRA K., SAMANTARAY, K. 2004. Interacting effects of dietary lipid level and temperature on growth, body composition and fatty acid profile of Rohu (Labeo rohita). Aquacult. Nutr., 10, 359-369. http://dx.doi.org/10.1111/j.13652095.2004.00311.x

OSMAN, F., JASWIR, I., KHAZAAI, H., HASHIM,R. 2007. Fatty acid profiles of finfish in Langkawi Island, Malaysia. J. Oleo. Sci.,56(3), 101-113. http://dx.doi.org/10.5650/jos.56.107

PAILWAN, I.F., MULEY, D.V., MASKE, S. 2008. Limnological features, plankton diversity and fishery status of three fresh water perennial tanks of Kolhapur district (MS) India. In: SENGUPTA, M., DALWANI, R. (Eds.) Proceedings of the $12^{\text {th }}$ World Lake Conference. pp: 1643-1649.

RAHMAN, S., TEH, S.H., OSMAN, H., DAUD, N.M. 1995. Fatty acid composition of some Malaysian freshwater fish. Food Chem., 54, 4549. http://dx.doi.org/10.1016/0308-8146(95)92660-c

RAVICHANDRAN, S., KUMARAVEL, K., FLORENCE, E.P. 2011. Nutritive consumption of some edible fin fishes. Int. J. Zool. Res., 7(3), 241-251. http://dx.doi.org/10.3923/ijzr.2011.241.251

RAVICHANDRAN, S., KUMARAVEL, K., RAMESHKUMAR, G., AJITHKUMAR, T.T. 2010. Antimicrobial peptides from the marine fishes. Res. J. Immunol., 3, 146-156. http://dx.doi.org/10.3923/rji.2010.146.156

RAZAK, Z.K.A., BASRI, M., DZULKEFLY, K., RAZAK, C.N.A., SALLEH, A.B. 2001. Extraction and characterization of fish oil from Monopterus albus Malaysian J. Anal. Sci., 7(1), 217-220.

SAIFY, Z.S., AKHTAR, S., HASSAN, S., ARIF, M., AHMED, F., SIDDIQUI, S. 2000. A study on fatty acid composition of fish oil form two marine fish, Eusphyra blochii and Carcharhinus bleekeri. Pak. J. Pharm. Sci., 13(2), 5-12.

SARGENT, J.R. 1997. Fish oils and human diet. British J. Nutr.,78(Suppl.1), S5S13. http://dx.doi.org/10.1079/bjn19970131

SIMOPOULOS, A.P. 2002. Omega-3 fatty acids in inflammation and autoimmune diseases. J. Am. Coll. Nutr., 21(6), 495 505. http://dx.doi.org/10.1080/07315724.2002.10719248

SIROT, V., OSEREDCZUK, M., BEMRAH-AOUACHRIA, N., VOLATIER, J.L., LEBLANC, J.C. 2008. Lipid and fatty acid composition of fish and seafood consumed in France: CALIPSO study. J. Food Comp. Anal., 21, 8-16. http://dx.doi.org/10.1016/j.jfca.2007.05.006

UGOALA, C., NDUKWE, G.I., AUDU, T.O. 2009. Investigation of the constituent fatty acids of some freshwater fishes common in Nigeria. Braz. J. Aquat. Sci. Technol., 13(1), 65-70. http://dx.doi.org/10.14210/bjast.v13n1.p6570

VLADAU, V.V., BUD, I., STEFAN, R. 2008. Nutritive value of fish meat comparative to some animals meat. Bull. UASVM Anim. Sci. Biotech., 65(1-2), 301-305.

WASIM, M.P. 2007. Issues, growth and instability of inland fish production in Sindh (Pakistan). Pakistan Econ. Soc. Rev., 45, 203-230.

WU T.H., PETER, B.J. 2008. Salmon by-product storage and oil extraction. Food Chem., 111, 868-871. http://dx.doi.org/10.1016/j.foodchem.2008.04.064

YADAV, C.N.R. 2006. Tilapia: an introduction and prospects of its culture in Nepal. Our Nature, 4, 107-110. http://dx.doi.org/10.3126/on.v4i1.511 